\title{
Knowledge Level of Physicians in Turkey about Hepatitis C and New Treatments
}

\section{Türkiye'deki Hekimlerin Hepatit C ve Yeni Tedavileri Konusundaki Bilgi Düzeyi}

\author{
๑ Ayşegül Inci Sezen, ๑ Kadriye Kart Yaşar \\ University of Health Sciences Turkey, Bakırköy Dr. Sadi Konuk Training and Research Hospital, Clinic of Infectious Diseases and Clinical Microbiology, \\ Istanbul, Turkey
}

\begin{abstract}
Objectives: The aim of this study was to evaluate the knowledge level of the physicians in Turkey about the ways of transmission of hepatitis $\mathrm{C}$, prevention, general clinical approach, and new hepatitis $\mathrm{C}$ treatment protocols and to increase awareness on this issue.

Materials and Methods: The study was conducted between January 2020 and March 2020 among physicians who were specialists and on specialty training. Three hundred and eight physicians were surveyed on hepatitis $\mathrm{C}$ diagnosis, treatment, and clinical approach.

Results: When asked whether hepatitis C was a notifiable disease, 88 physicians (28.6\%) answered "no", while 167 physicians (54.2\%) answered "yes". While 33.6\% of surgical branches had the correct answer that the disease was transmitted by birth in terms of the transmission route, it was found that $20 \%$ of physicians answered correctly in non-surgical branches. When the curative treatment of hepatitis $\mathrm{C}$ was asked, 70 physicians $(22.7 \%)$ answered that there was no treatment, while $238(77.3 \%)$ physicians answered that there was a definitive treatment.

Conclusion: With the use of direct-acting antivirals in hepatitis C infection, the chance of cure has increased greatly, and the fact that physicians are not fully aware of this new information may cause deficiencies in the patients' guidance.
\end{abstract}

Keywords: Chronic viral hepatitis C, antiviral agents, clinical protocols

\section{ÖZ}

Amaç: Çalışmanın amacı Türkiye'deki uzmanlık eğitimi alan ya da uzman olan hekimlerin hepatit C'nin bulaş yolları, korunma, genel klinik yaklaşım ve yeni hepatit $\mathrm{C}$ tedavi protokolleri konusundaki bilgi düzeylerini değerlendirmek ve bu konudaki farkındalığı artırmaktır. Gereç ve Yöntemler: Çalışmada, Ocak 2020 ile Mart 2020 tarihleri arasında uzman ve uzmanlık eğitimi alan hekimlere hepatit $C$ tanı, tedavi ve klinik yaklaşımları konularında anket uygulandı. Çalışmadaki 308 hekim dahili ve cerrahi branşlar olarak iki grup altında değerlendirildi.

Bulgular: Hepatit C'nin bildirimi zorunlu bir hastalık olup olmadığı sorulduğunda 88 hekim $(\% 28,6)$ hayır olarak cevaplarken, 167 hekim $(\% 54,2)$ evet olarak belirtti. Cerrahi branşların \%33,6'sı hastalığın bulaşma yolu açısından doğumla bulaşabildiği doğru cevabını verirken, dahili branş hekimlerinin \%20'sinin doğru cevap verdiği görüldü. Hepatit C'nin küratif tedavisi değerlendirildiğinde 70 hekim $(\% 22,7)$ "tedavisi yok" olarak cevaplarken, "kesin tedavisi var" diyen $238(\% 77,3)$ hekim mevcuttu.

Sonuç: Direk etkili antivirallerin hepatit C enfeksiyonunda kullanılması ile birlikte kür şansı çok artmış olup bu yeni bilgiye hekimlerin tam hakim olmamaları hastaların yönlendirilmesinde eksikliklere neden olabilir.

Anahtar Kelimeler: Kronik viral hepatit C, antiviral ajanlar, klinik protokoller

Sezen Al, Kart Yaşar K. Knowledge Level of Physicians in Turkey about Hepatitis C and New Treatments. Viral Hepat J. 2021;27:136-141.

Address for Correspondence: Ayşegül Inci Sezen MD, University of Health Sciences Turkey, Bakırköy Dr. Sadi Konuk Training and Research Hospital, Clinic of Infectious Diseases and Clinical Microbiology, Istanbul, Turkey 


\section{Introduction}

More than 1.4 million people die every year in the world due to acute hepatitis infection, hepatitis-related liver cancer, and cirrhosis. Unless action is taken, it is believed that by 2040 , hepatitis B- and hepatitis C-related deaths will affect a larger population than that of deaths from human immunodeficiency virus, tuberculosis, and malaria (1). Hepatitis $C$ is the main cause of liver cancer and liver transplant. It is known that approximately 400,000 people die of hepatitis C-related causes every year (2). Most of these deaths from hepatitis $\mathrm{C}$ could be completely prevented if people were aware of hepatitis $\mathrm{C}$ virus (HCV) infection and had access to appropriate treatment (3). For all of these reasons, hepatitis $C$ is one of the most important current health problems. In Turkey, the incidence of hepatitis C is approximately $1 \%$ (4).

Hepatitis $C$ is transmitted from an infected mother to the baby during delivery, rarely by unprotected sexual contact with an infected partner, through contacts such as blood and blood products transfusion, solid organ transfusion from an infected donor, intravenous (IV) drug use, unsafe therapeutic injections, and occupational exposures such as needle-sticks $(4,5,6)$. Among these, the most important transmission routes are blood transfusion from a donor who has not been screened, IV drug use, and unsafe therapeutic injections $(7,8)$. Knowing the ways in which it can be transmitted is necessary so as to provide protection. An important step toward the eradication of this disease may lie in having the knowledge that it is possible to treat it with newly developed direct antivirals by healthcare professionals and referring those who have the disease to infectious diseases and gastroenterology physicians so that they can be treated. Nowadays, curative treatment options for hepatitis $\mathrm{C}$ disease have been found, and persistent virological responses that exceed 95\% have been obtained (9). Treatment protocols are constantly changing today, and when the literature was evaluated, there were insufficient studies that have evaluated the level of knowledge of physicians about hepatitis $C$ transmission routes and new treatments.

The aim in this study was to evaluate the knowledge level of physicians who have been in training or who are specialists in Turkey, about the ways in which hepatitis $\mathrm{C}$ can be transmitted, the clinical approach toward the disease, and new treatment protocols.

\section{Materials and Methods}

The study was conducted on physicians who were specialists or were receiving specialty training between January and March 2020. There were 21 questions in the questionnaire about hepatitis $\mathrm{C}$ disease for the physicians. Multiple-choice questionnaire forms were prepared, which included both correct and incorrect answers for the physicians to choose from. Physicians from internal branches (internal medicine, pediatrics, chest diseases, cardiology) and surgical branches (thoracic surgery, general surgery, cardiovascular surgery, otolaryngology, orthopedics, neurosurgery, gynecology, ophthalmology) were included in the study. A total of 308 physicians, 149 of whom were in internal branches and 159 surgeons from surgical branches, participated in the study. Infectious diseases and gastroenterology physicians were excluded from the study because they were working in a relevant branch, assuming that they had this knowledge. In addition, incomplete questionnaires were excluded from the study.
The demographic characteristics of the physicians, epidemiology of hepatitis $\mathrm{C}$, transmission routes, approaches to diagnosis, and current treatment options were asked about in the survey.

The study was approved by Ethics Committee Yedikule Chest Diseases and Thoracic Surgery Research and Education Hospital (approval number: 2021-109, date: 08.04.2021) and was conducted in accordance with the principles of the Declaration of Helsinki. Authors took informed consent from all participants in this study.

\section{Statistical Analysis}

Chi square analysis was applied to show the relationship between the demographic data of the physicians and descriptive statistics and categorical data, and $p<0.05$ was considered as statistically significant. IBM SPSS Statistics for Windows 22.0 (IBM Corp., Armonk, NY, USA) was used for the calculations.

\section{Results}

There were 160 female (51.9\%) and 148 male (48.1\%) physicians included in the study. The average age of the physicians was $36.1 \pm 6.1$ years, and there were $71(23.1 \%)$ individuals aged 40 and over, and 237 (76.9\%) who were under 40 years of age. Moreover, 149 (48.4\%) physicians were from surgical branches and $159(51.6 \%)$ were from internal branches. With regard to the specialist physicians, the average number of years that they had spent as a specialist was 9.6 \pm 5.7 . There were 62 residents and 246 specialist physicians in the study (Table 1).

While 13 of the surgical physicians had not had hepatitis C screening tests before, 136 of the surgery physicians $(91.3 \%)$ had previously had hepatitis $\mathrm{C}$ screening tests. While 23 of the internal physicians had not had hepatitis C screening test before, 136 (85.5\%) had previously had a screening test for hepatitis $\mathrm{C}$. There were no statistically significant differences between the groups $(p=0.11)$. When asked whether hepatitis $C$ is a notifiable disease, 88 physicians (28.6\%) answered no, 167 physicians (54.2\%) answered yes, and 53 (17.2\%) answered I do not know. Of the surgical sciences, 38 (25.5\%) physicians answered no, 86 (57.7\%) answered yes, and 25 (16.8\%) did not know. Fifty physicians from internal sciences answered the same question as no (31.4\%), 81 physicians (50.9\%) answered yes, and 28 physicians (17.6\%) answered I do not know. There were no statistically significant differences between the groups $(p=0.44)$.

Table 2 contains details of the questions asked to the physicians in the questionnaire to examine their knowledge of transmission routes.

When the physicians were asked which tests should be ordered in the diagnosis of hepatitis $\mathrm{C}$, the number of physicians who gave HCV-RNA and anti-HCV responses together was 160 (51.9\%). While there were 74 physicians $(49.7 \%$ ) who marked the correct diagnostic test options in the surgical departments, this number was $86(54.1 \%)$ in the internal sciences $(p=0.43)$. While $112(70 \%)$ of the physicians who knew the correct diagnostic tests had 10 years or less of specialization, 48 (43.2\%) physicians with a specialization duration of more than 10 years answered the question correctly, and a statistically significant difference was found $(p=0.02)$. When the answers of the physicians to the questions about the course of hepatitis $C$ were evaluated, 146 physicians $(47.4 \%)$ stated that hepatitis C could be treated 


\begin{tabular}{|c|c|c|c|}
\hline \multicolumn{2}{|l|}{ Variables } & n & $\%$ \\
\hline \multicolumn{2}{|c|}{ Age (year) (mean $\pm \mathrm{SD}$ ) } & \multicolumn{2}{|c|}{$35.1 \pm 6.1$} \\
\hline Gender & Female & 160 & 51.9 \\
\hline Age (year) & $<40$ & 237 & 76.9 \\
\hline Branches & İnternal & 159 & 51.6 \\
\hline \multicolumn{2}{|c|}{ Specialty duration (mean \pm SD) (year) } & \multicolumn{2}{|c|}{$9.6 \pm 5.7$} \\
\hline \multirow{2}{*}{ Specialty duration } & $<10$ & 197 & 64 \\
\hline & $>10$ & 111 & 36 \\
\hline
\end{tabular}

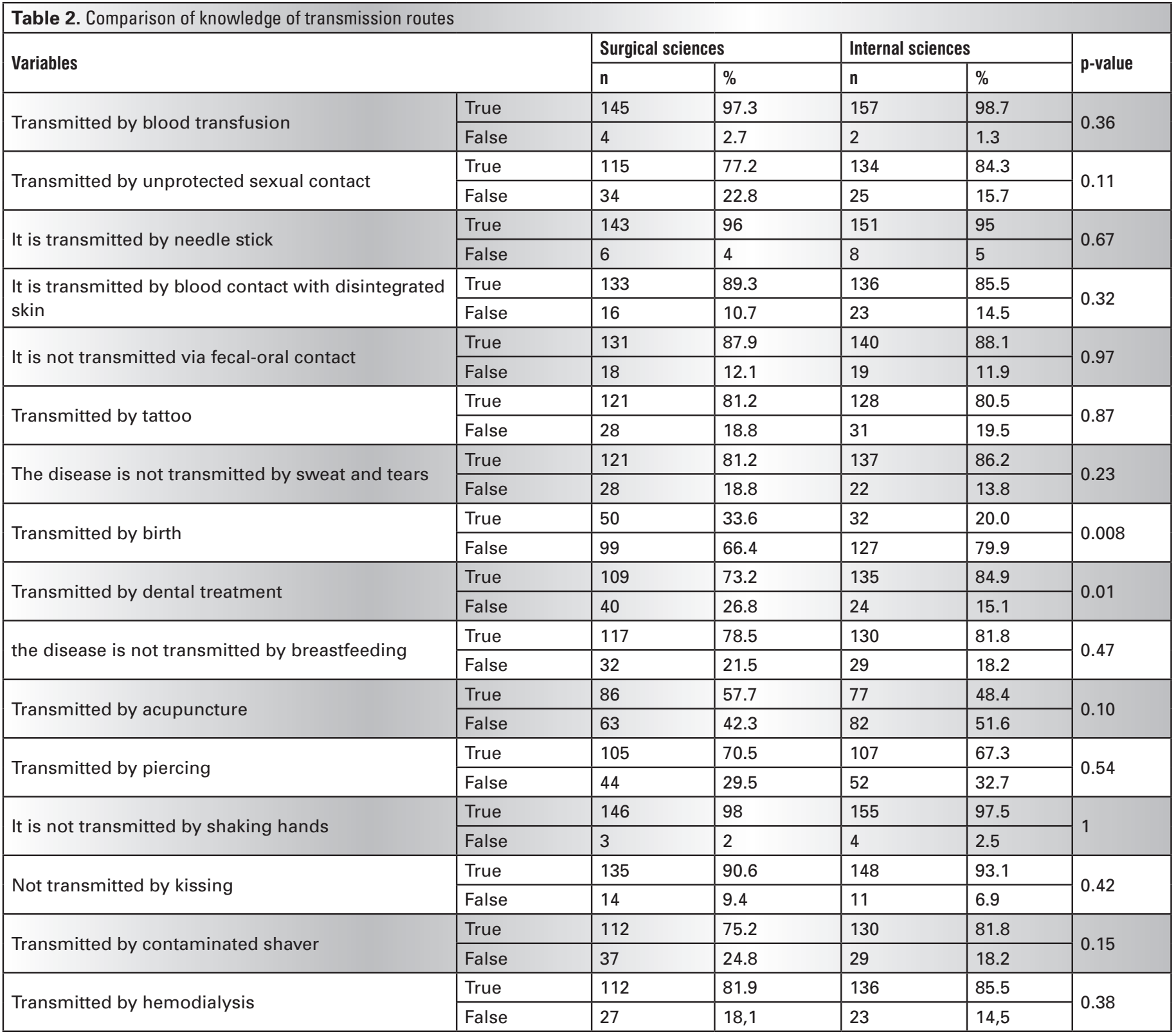


spontaneously. When the curative treatment of hepatitis $\mathrm{C}$ was questioned, 70 physicians $(22.7 \%)$ thought that there was no full cure treatment and 238 (77.3\%) thought that there was a definitive treatment. While there were $115(77.2 \%)$ surgeons and 123 $(77.4 \%)$ medical practitioners who knew that there is a curative treatment of hepatitis $C(p=0.97)$; the correct response rate was $73.9 \%$ in physicians who had been specialists for 10 years or more, and $79.2 \%$ in physicians who had specialized for less than 10 years $(p=0.28)$. When asked if hepatitis $C$ does not cause sudden death, 255 physicians (82.2\%) answered correctly. When asked if hepatitis C causes cirrhosis in the long term, 294 physicians (95.5\%) answered the question correctly. While the number of physicians who correctly knew that there were oral antiviral treatment options in the treatment was $130(42.2 \%)$, there were 284 physicians $(92.2 \%)$ who thought that a hepatitis $C$ vaccine was available. Table 3 contains the comparison of the responses of the physicians regarding the diagnosis, treatment, and prognostic approaches of hepatitis $\mathrm{C}$ according to their branches.

In the table, it can be seen that $47.7 \%$ of the physicians $(n=147)$ answered that they approached all patients similarly when an invasive procedure was going to be performed in HCV positive patients. Moreover, $44.5 \%(n=137)$ stated that sent the patient to consult with infectious diseases specialists before the procedure, and $2.99 \%(n=9)$ would refer the patient to a higher-level center. While only 3 physicians (1\%) stated that they would withdraw from the interventional procedure, 2 physicians $(0.6 \%)$ stated that they would reevaluate the surgical indication.

\section{Discussion}

The aim of this study was to evaluate whether the information about patients with $\mathrm{HCV}$, which can be seen widely in internal and surgical clinics, is up-to-date and accurate in terms of new therapies and patient management. The questions asked in the questionnaire were guiding questions that had selectivity and reliability, and they aimed not only to measure the knowledge level of the physicians on the subject, but to also raise awareness by arousing their curiosity. The questionnaire aimed to distinguish the current level of knowledge and awareness of internal and surgical clinic department physicians. Studies in the UK, Australia, and the USA have suggested that there are gaps in HCV knowledge among clinical physicians, primary care physicians, and other healthcare professionals $(10,11,12)$. In a study conducted by Coppola et al. (10), which examined HCV information among physicians providing primary health care services in the USA, it was revealed that there were mistakes in the $\mathrm{HCV}$ information. Although there is currently no $\mathrm{HCV}$ vaccine available, $66 \%$ of healthcare professionals recommended vaccinating people with an $\mathrm{HCV}$ vaccine. In the current study, there were internal physicians $(5.7 \%)$ and surgical physicians $(10.1 \%)$ who thought that there was a vaccine for hepatitis $\mathrm{C}$. Studies have shown that many physicians, including primary care physicians, not only medical school students receiving education, have insufficient knowledge about HCV (13). In this study, it was found that the number of surgical physicians (49.7\%) and internal physicians (54.1\%) who knew the diagnostic tests that are required to diagnose HCV was extremely low.

\begin{tabular}{|c|c|c|c|c|c|c|}
\hline \multirow{2}{*}{\multicolumn{2}{|c|}{ Variables }} & \multicolumn{2}{|c|}{ Surgical clinics } & \multicolumn{2}{|c|}{ Internal clinics } & \multirow{2}{*}{ p-value } \\
\hline & & $n$ & $\%$ & $n$ & $\%$ & \\
\hline \multirow{2}{*}{$\begin{array}{l}\text { Diagnostic tests in HCV are anti-HCV and } \\
\text { HCV-RNA }\end{array}$} & True & 74 & 49.7 & 86 & 54.1 & \multirow{2}{*}{0.43} \\
\hline & False & 75 & 50.3 & 73 & 48.9 & \\
\hline \multirow{2}{*}{ HCV can be curatively treated } & True & 115 & 77.2 & 123 & 77.4 & \multirow{2}{*}{0.96} \\
\hline & False & 34 & 22.8 & 36 & 22.6 & \\
\hline \multirow{2}{*}{ HCV has a treatment } & True & 125 & 77.2 & 123 & 77.4 & \multirow{2}{*}{0.97} \\
\hline & False & 34 & 22.8 & 36 & 22.6 & \\
\hline \multirow{2}{*}{ HCV can recover spontaneously } & True & 56 & 37.6 & 90 & 56.6 & \multirow{2}{*}{0.001} \\
\hline & False & 93 & 62.4 & 39 & 43.4 & \\
\hline \multirow{2}{*}{ Sudden death can occur in HCV } & Can not occur & 121 & 81.2 & 134 & 84.3 & \multirow{2}{*}{0.47} \\
\hline & Can occur & 28 & 18.8 & 25 & 15.7 & \\
\hline \multirow{2}{*}{ HCV causes cirrhosis } & True & 137 & 91.9 & 157 & 98.8 & \multirow{2}{*}{0.004} \\
\hline & False & 12 & 8.1 & 2 & 1.3 & \\
\hline \multirow{2}{*}{ Over $95 \%$ of $\mathrm{HCV}$ is curative } & True & 61 & 40.9 & 69 & 43.4 & \multirow{2}{*}{0.66} \\
\hline & False & 88 & 59.1 & 90 & 56.6 & \\
\hline \multirow{2}{*}{$\begin{array}{l}\text { There are oral treatment options in the } \\
\text { treatment of HCV }\end{array}$} & True & 41 & 27.5 & 89 & 56 & \multirow{2}{*}{$<0.001$} \\
\hline & False & 108 & 72.4 & 70 & 44 & \\
\hline \multirow{2}{*}{ Hepatitis $C$ does not have a vaccine } & True & 134 & 89.9 & 150 & 94.3 & \multirow{2}{*}{0.14} \\
\hline & False & 15 & 10.1 & 9 & 5.7 & \\
\hline \multirow{2}{*}{$\begin{array}{l}\text { Pre-operative screening test should be } \\
\text { done }\end{array}$} & True & 140 & 94 & 144 & 90.6 & \multirow{2}{*}{0.26} \\
\hline & False & 9 & 6 & 15 & 9,4 & \\
\hline
\end{tabular}


Mencl et al. (11) evaluated the knowledge of universal precautions among emergency medical professionals and stated that $22 \%$ of the healthcare professionals thought that hepatitis could be transmitted by air. Most healthcare workers in studies done abroad described the main routes of transmission as blood transfusions, exposure to blood during sexual activity, and sharing needles while injecting drugs $(14,15)$. None of the questions in the survey herein were answered $100 \%$ correctly. When asked about the risk of contagion with a needle stick, 6 of the 149 surgical physicians and 8 of the 159 internal physicians said that there was no risk of hepatitis $\mathrm{C}$ transmission through needle stick injury.

Bianco et al. (14) stated in their study that they thought that $12 \%$ of nurses working in hemodialysis clinics in Italy could transmit HCV by kissing. In addition, 19\% of the nurses emphasized that they did not know that tattooing can be a way to transmit HCV. In the current study, it was observed that $81.2 \%$ of the surgical clinic physicians and $80.5 \%$ of the internal clinic physicians knew that it could be transmitted by tattooing. While the rate of surgeons who thought that HCV could be transmitted by kissing was $9.4 \%$ and the rate of physicians in the internal clinics was $6.9 \%$.

In this study, when the information about the transmission routes was examined, it was observed that there were deficiencies in the knowledge that hepatitis $\mathrm{C}$ can be transmitted through birth, where $33.6 \%$ of the surgeons and $20 \%$ of the internal sciences physicians knew that hepatitis $\mathrm{C}$ could be transmitted through birth. While the level of knowledge in both branches was actually low (below 50\%), it was statistically observed that the level of knowledge in the internal clinics was significantly lower $(p=0.008)$. In this respect, the fact that the surgical clinics have more knowledge than internal clinics may be that the branch of obstetrics, which deals with labor and births, is within the surgical clinics.

In a study of Brazilian dentists, $20 \%$ of dentists said there was no risk of $\mathrm{HCV}$ transmission during dental treatment, and $13 \%$ believed there was an HCV vaccine, showing a lack of clear information about HCV (16). In the current study, there were no dentists participating. When dental treatment and hepatitis $\mathrm{C}$ transmission were questioned, $73.2 \%$ of the surgeons and $84.9 \%$ of the internal physicians gave the correct answer. It was observed that the knowledge of the internal physicians on this issue was significantly higher $(p=0.01)$. Most of the studies carried out showed that there is a lack of knowledge about hepatitis $\mathrm{C}$ and that it would be appropriate to develop training programs to update the knowledge of these physicians (11). Another study that looked at the knowledge levels of risk groups and young adults in the community showed that the percentage of correct answers about awareness was $54 \%$ and $43 \%$, respectively (17).

Two recent studies, published after the introduction of new interferon-free direct-acting antiviral (DAA) treatments, focused on whether the curability of $\mathrm{HCV}$ is known (18). Among health care providers, the specialists (i.e. hepatologists, gastroenterologists, and hepatology nurses) scored higher than the practitioners in questionnaires measuring information about HCV treatment. In the survey, 7 of the 10 primary care physicians were not aware of the new interferon-free DAAs and their mechanism of action (18). In our study, the rate of surgical physicians who knew that hepatitis $\mathrm{C}$ had oral treatment with DAAs was $27.5 \%$, while the rate of internal physicians who thought the same was $56 \%$. Moreover, the difference was statistically significant $(p<0.001)$. The rate of surgical physicians who thought that the treatment of hepatitis $\mathrm{C}$ was over $95 \%$ successful was $40.9 \%$, while the rate of internal physicians who thought the same was $43.4 \%$. The information that patients who have hepatitis $\mathrm{C}$ can recover spontaneously was known by $37.6 \%$ of those in the surgical branches and $56.6 \%$ of those in the internal clinics. The difference between them was statistically significant and drew attention to the lack of knowledge of surgical physicians on this subject.

\section{Study Limitations}

The small sample size in the study and the fact that it was a survey study increased the degree of bias.

\section{Conclusion}

With the use of DAAs in hepatitis $C$ infection, the chance of cure has increased a great deal, and it may be accepted as natural that this new information is unknown to physicians who do not primarily deal with this issue, except infectious physicians and gastroenterologists. However, since their lack of full knowledge of this issue may cause deficiencies in the referral of patients, it may result in them missing patients who have a chance to be cured, so all physicians should be given in-service information about new information and developments on infectious diseases so that physicians can update themselves. Emphasizing the importance of updating the information learned during medical school education and raising awareness of advancing medical science and emerging treatments and interventions will make a difference in terms of both healthcare providers, patients benefiting from healthcare services and improving public health.

\section{Ethics}

Ethics Committee Approval: The study was approved by Ethics Committee Yedikule Chest Diseases and Thoracic Surgery Research and Education Hospital (approval number: 2021-109, date: 08.04.2021).

Informed Consent: Authors took informed consent from all particiant in this study.

Peer-review: Externally peer-reviewed.

\section{Authorship Contributions}

Concept: A.I.S., K.K.Y., Design: A.I.S., K.K.Y., Supervision: A.I.S., K.K.Y., Resources: A.I.S., K.K.Y., Materials: A.I.S., K.K.Y., Data Collection and/or Processing: A.I.S., K.K.Y., Analysis and/or Interpretation: A.I.S., K.K.Y., Literature Search: A.I.S., K.K.Y., Writing Manuscript: A.I.S., K.K.Y., Critical Review: A.I.S., K.K.Y.

Conflict of Interest: No conflict of interest was declared by the author.

Financial disclosure: The authors declared that this study received no financial support. 


\section{References}

1. Thomas DL. Global elimination of chronic hepatitis. N Engl J Med. 2019;380:2041-2050.

2. World Health Organization. Progress report on HIV, viral hepatitis and sexually transmitted infections 2019: accountability for the global health sector strategies, 2016-2021. World Health Organization; 2019.

3. Waheed $Y$, Siddiq M, Jamil Z, Najmi MH. Hepatitis elimination by 2030: Progress and challenges. World J Gastroenterol. 2018:24:4959-4961.

4. Barut HŞ, Günal Ö. Global and National Epidemiology of Hepatitis C. Klimik Derg. 2009;22:38-43. Turkish.

5. Inci A. Investigation of Hepatitis B and Hepatitis C Seroprevalence in HIV-Infected Patients. Klimik Derg. 2018;31:34-36. Turkish.

6. Bayır H, Yıldız I, Koçoğlu E, Kurt AD, Koçoğlu H. Seroprevalence of hepatitis $B$, hepatitis $C$ and HIV in intensive care unit patients. $J$ Turkish Soc Intens Care. 2015;13:75-78.

7. Lavanchy D. The global burden of hepatitis C. Liver Int. 2009;29(Suppl1):74-81.

8. Alter MJ. Epidemiology of hepatitis C virus infection. World J Gastroenterol. 2007;13:2436-2441

9. Öztürk-Çerik H, Esen Ş, Altıntaş-Öner B, Çelik M, Özdemir T, Tanyel E. Evaluation of the effectiveness of direct-acting antiviral agents in patients with hepatitis C. Klimik Derg. 2020;33:297-306. Turkish.

10. Coppola AG, Karakousis PC, Metz DC, Go MF, Mhokashi M, Howden CW, Raufman JP, Sharma VK. Hepatitis C knowledge among primary care residents: is our teaching adequate for the times? Am J Gastroenterol. 2004;99:1720-1725.
11. Mencl F, Birkle M, Blanda M, Gerson LW. EMTS' knowledge regarding transmission of infectious disease. Prehospital Emerg Care. 2000;4:57-61.

12. Zickmund SL, Brown KE, Bielefeldt K. A systematic review of provider knowledge of hepatitis $\mathrm{C}$ : is it enough for a complex disease? Dig Dis Sci. 2007;52:2550-2556

13. D'Souza RFC, Glynn MJ, Alstead E, Osonayo C, Foster GR Knowledge of chronic hepatitis $\mathrm{C}$ among East London primary care physicians following the Department of Health's educational campaign. Qjm. 2004;97:331-366.

14. Bianco A, Bova F, Nobile CGA, Pileggi C, Pavia M; Collaborative Working Group. Healthcare workers and prevention of hepatitis $C$ virus transmission: exploring knowledge, attitudes and evidencebased practices in hemodialysis units in Italy. BMC Infect Dis. 2013;13:1-11

15. Todorova TT, Tsankova G, Tsankova D, Kostadinova T, Lodozova N. Knowledge and attitude towards hepatitis $B$ and hepatitis $C$ among dental medicine students. J IMAB-Annual Proceeding Sci Pap. 2015;21:810-813.

16. Takahama AJ, Tatsch F, Tannus G, Lopes MA. Hepatitis C: incidence and knowledge among Brazilian dentists. Community Dent Health. 2005:22:184-187.

17. Balfour L, Kowal J, Corace KM, Tasca GA, Krysanski V, Cooper CL, et al. Increasing public awareness about hepatitis C: Development and validation of the brief hepatitis C knowledge scale. Scand J Caring Sci. 2009;23:801-808.

18. Naghdi R, Seto K, Klassen C, Emokpare D, Conway B, Kelley M, Yoshida E, Shah HA. A hepatitis C educational needs assessment of Canadian healthcare providers. Can J Gastroenterol Hepatol. 2017;2017:5324290 